IN MEMORIAM 


\title{
TEMÍSTOCLES LINHARES \\ 1905-1993
}

\author{
Marta Morais da Costa*
}

\section{A}

edição do número da Revista Letras correspondente ao ano de 1993 já estava em fase final de composiçào quando se divulgou a notícia da morte do Prof. Temístocles Linhares, um de seus fundadores em 1953 e seu editor no período de 1972 a 1974. Cremos, porém, que o registro e a homenagem que lhe fazemos na presente edição embora tardios não serão menos significativos.

Homenageamos no prof. Linhares o crítico literário que faz parte da história brasileira no século XX, o estudioso dedicado aos assuntos paranaenses e o mestre cuja carreira docente e administrativa mereceu da Universidade Federal do Paraná, em 1970, o reconhecimento público pela outorga do título de Professor Emérito.

De sua obra publicada, vasta e significativa, ressaltamos a Introduçăo ao mundo do romance (1953), Parana novo, um retrato sem retoques (1953) ampliada e com novo título em sua segunda edição: Paranci vivo, sua vida, sua gente, sua cultura (1985) - História econômica do mate (1968), 22 Diálogos sobre o conto brasileiro atual (1978), Dialogos sobre a poesia brasileira (1976) e Dialogos sobre o romance brasileiro (1978).

* Universidade Federal do Paraná 
Foi colaborador ao longo de sua vida de jornais do Rio de Janeiro (Diário de Notícias, Correio da Manhã, OJornal, A Manhã), de São Paulo (Folha da Manhã, $O$ Estado de São Paulo, Diário de São Paulo) e de revistas nacionais como Anhembi, Revista do Liıro, Letras e Vertice. Tem obras sobre Eça de Queirós, Raul Pompéia, Machado de Assis e Carlos Nejar.

Foi docente, entre 1965 e 1967, na Universidade de Coimbra em Portugal, na qualidade de professor de Literatura Brasileira e História do Brasil. Na Universidade Federal do Paraná aposentou-se como professor titular de Literatura Brasileira e Literatura Hispanoamericana.

No presente número da Revista Letras, dedicado ao romance, prestamos nosso preito de admiração pelo crítico desaparecido, reproduzindo seu artigo publicado em Letras no ano de 1982. Acreditamos que, para um intelectual que viveu da leitura e da escrita, sua palavras, ecoando em novos leitores, realizarão um dos modos de ser da escrita: a permanência, índice de eternidade. 